\title{
STUDIES ON ACINOS ALPINUS L.: POLYPHENOLS AND TERPENOIDS COMPOUNDS PROFILE, ANTIMICROBIAL ACTIVITY, ANTIOXIDANT EFFECT AND RELEASE EXPERIMENTS ON THE ETHANOL AND PROPYLENE GLYCOL EXTRACTS
}

\author{
LUCIA PÎRVU ${ }^{1}$, FAWZIA SHA’AT ${ }^{1}$, RAMONA PĂVĂLOIU ${ }^{1}$, DENISA IOANA UDEANU ${ }^{2}$, \\ BUJOR ALBU ${ }^{1} *$ \\ ${ }^{1}$ National Institute of Chemical Pharmaceutical R\&D (INCDCF), 112 Vitan Road, 031299, Bucharest, Romania \\ 2 "Carol Davila" University of Medicine and Pharmacy, Faculty of Pharmacy, Department of Clinical Laboratory and Food \\ Safety, 6 Traian Vuia Street, 020956, Bucharest, Romania
}

*corresponding author: abujor@gmail.com

Manuscript received: March 2019

\begin{abstract}
The present study aims to evaluate the chemical profile, antioxidant and antimicrobial activities, as well as diffusion aspects of the active compounds (polyphenols and terpenoids) in a physiological saline solution, of two extracts from the aerial part of rock thyme, Acinos alpinus (L.) Moench. The extract in 70\% ethanol (E18) was used to evaluate the chemical qualitative and quantitative composition of polyphenols and terpenoids, and to assess the scavenger activity and antioxidant properties (chemiluminescence method); the extract in $20 \%$ propylene glycol (P18) was used to test the antimicrobial effect on $E$. coli ATCC 8739, S. aureus ATCC 25923 and C. albicans ATCC 10231, and also in diffusion studies on Franz cell device through the use of a synthetic membrane of cellulose acetate type in physiological saline media, in order to evaluate the diffusion effectiveness of the active compounds supported on sugar and water, respectively.
\end{abstract}

\section{Rezumat}

Scopul acestui studiu a constat în evaluarea compoziţiei chimice calitative şi cantitative, a potenţialului antioxidant şi antimicrobian, precum și a unor caracteristici privind difuzia compuşilor activi (polifenoli si terpenoide) în mediu de ser fiziologic, a două extracte obținute din partea aeriană de cimbrișor de stâncă, Acinos alpinus (L.) Moench, cunoscut îndeosebi pentru proprietăţile aperitive şi digestive. Astfel, extractul în etanol 70\% (E18) a fost utilizat pentru evaluarea conținutului chimic în polifenoli și terpenoide, dar și pentru estimarea capacității de îndepărtare a radicalilor liberi din mediu, respectiv a efectului antioxidant (studii de chemiluminescență); extractul în propilen glicol 20\% (P18) a fost utilizat pentru testarea efectului antimicrobian pe tulpini de E. coli ATCC 8739, S. aureus ATCC 25923 și C. albicans ATCC 10231, respectiv în studii de difuzie (pe celula Franz) utilizând o membrană sintetică de tip acetat de celuloză în mediu de ser fiziologic, cu scopul final al demonstrării eficacităţii cedării compușilor activi din suport apă, respectiv zahăr.

Keywords: rock thyme, Acinos alpinus, chemical composition, antioxidant effect, diffusion studies

\section{Introduction}

Acinos species (Lamiaceae family) are known to live in cold places, in mountains or moorlands regions, in Europe, Turkey and the north of Africa and America. Data [26] indicates that Acinos genus includes 11 species with numerous synonyms; Acinos alpinus (L.) Moench, also known as rock thyme, can be found as Satureja alpina (L.) Scheele, Acinos baumgartenii (Simonk.) Klokov, Acinos alpinus subsp. baumgartenii (Simonk.) Pawl.1, Melissa baumgartenii (Simonk.), Clinopodium alpinum (L.) Merino, Calamintha alpina (L.) Lam., and Calamintha alpina (L.) Lam. subsp. alpina. In the Romanian Carpathians, Acinos alpinus species can be found at altitudes above $1400 \mathrm{~m}$.

Regarding its medicinal use, in Spain, Acinos alpinus plant species are included in the category of (alimentary) herbal teas; the popular name of the species is té de campo, té de roca, poleo montesino, etc. Té de campo is very appreciated for the special aroma, due to the specific content of pulegone, menthone, limonene and alpha-pinene(iv) volatile oil compounds [19].

Ethno-pharmaco-botanical records [19] in Spain describe Acinos alpinus plant species with antiseptic, antispasmodic, anti-inflammatory, cholesterol lowering, and even anti-catarrhal properties, as well as having benefits on the gastrointestinal and urinary systems. It is recommended as digestive, aperitif, anti-diarrhoeic, diuretic and slimming natural remedy.

Romanian folk medicine does not have data or recommendations on the use of the Acinos alpinus plant species.

Scientific data on Acinos species is scarce and it mainly describes the volatile oils content and their antioxidant, antimicrobial, and anti-inflammatory properties. For 
instance, the volatile oil fraction from Acinos arvensis sp. was proved to be effective against E. coli, $S$. aureus and $K$. pneumonia strains, while Acinos suaveolens sp. volatile oil fraction proved efficacy against $E$. coli, $S$. aureus, S. epidermidis, S. hominis and K. pneumonia strains [26]. Ulukanli et al. [29] also proved the high efficacy of acetone extracts isolated from the roots and the aerial part of Acinos rotundifolius Pers. plant species on nine standard bacterial strains; S. aureus Cowan 1, M. luteus LA 2971, Mycobacterium smegmatis CCM 2067, Bacillus subtilis IGM 22, Bacillus subtilis var. Niger ATCC 10, Aeromonas hydrophila ATCC 7966, K. pneumoniae FMC 5, Pseudomonas aeruginosa ATCC 27853, and C. albicans ATCC 10231. Similarly, the volatile oil fraction from Acinos arvensis Dandy plant species indicated antimicrobial activity against E. coli, $S$. aureus and K. pneumoniae strains [11]. Jennan S. et al. [10] studied the antioxidant and anti-inflammatory properties of the volatile oils fractions isolated from Satureja alpina (syn. Acinos alpinus), Satureja briquetti and Satureja atlantica Morocco plant species; the paw oedema carrageenan induced rat model in vivo using as standard a synthetic antioxidant compound namely butylated hydroxytoluene (BHT) indicated that $S$. alpina volatile oils fraction provided the best anti-inflammatory effects; doses of $200 \mathrm{mg}$ volatile oils per $\mathrm{kg}$ body weight were estimated with $91.4 \%$ inhibitory activity upon paw oedema induced inflammation. Also, the leaves extract from Calamintha grandiflora Moench, C. nepeta Savi and C. sylvatica Bromf. were reported to have antioxidant effects $[2,3]$. This study aimed to evaluate the chemical qualitative and quantitative aspects of the active compounds (polyphenols and terpenoids) found in ethanol and propylene glycol extracts from Acinos alpinus L., responsible for the flavour and bitter properties of the species. Antioxidant activity and antimicrobial properties of the two extracts were also evaluated. Diffusion studies on Franz cell device through the use of a synthetic membrane of cellulose acetate type, physiological saline media, and sugar and water supported Acinos alpinus propylene glycol extracts have been done, with the final purpose of designing new products beneficial for digestion processes.

\section{Materials and Methods}

Plant material. The fresh aerial part (herba et flores) of Acinos alpinus L. (fam. Lamiaceae), commonly named rock thyme, has been collected in June 2018 from Romanian Carpathians, Bucegi Mountains respectively (Sinaia region), at about $1400 \mathrm{~m}$ altitude. Taxonomic identification of the plant material has been done by the botanist's team of the National Institute for Chemical Pharmaceutical R\&D, ICCF Bucharest, Romania; a voucher specimen (Aalp0518) is deposited in the Plant Material Storing Room of ICCF. The plant material has been shading dried and minced into a fine plant powder, then used in technological studies.

Plant extracts' preparation. Two charges of ten (10) grams of plant powder were separately extracted with $200 \mathrm{~mL}$ of $70 \%(\mathrm{v} / \mathrm{v})$ ethanol solution, one hour at $82^{\circ} \mathrm{C}$. The two ethanolic extracts $(150 \mathrm{~mL}$ each $)$ were filtered and mixed. The resulted $70 \%$ ethanolic extract (codified E18) has been analysed as concerning chemical qualitative and chemical quantitative aspects. Further, fifty (50) $\mathrm{mL}$ of E18 has been hydrolysed for 30 minutes in $4 \mathrm{~N} \mathrm{HCl}$ environment. The resulted filtrate sample has been evaporated to dryness and the solid matter obtained (spiss product) was redissolved into $98 \%$ ethanol solvent to a final volume of $50 \mathrm{~mL}$. The resulting (ethanolic) hydrolysate sample (codified H18) was also analysed as concerning qualitative (HP)TLC aspects. In parallel, one hundred (100) $\mathrm{mL}$ of E18 were concentrated at low pressure (Büchi Rotary Evaporator) and the resulted spiss product was solved into $20 \%(\mathrm{v} / \mathrm{v})$ propylene glycol solution in order to assure the final content of $5 \mathrm{mg}$ total phenols content expressed as gallic acid equivalents (GAE) per $1 \mathrm{~mL}$ sample. The resulted standardized $20 \%$ propylene glycol extract (codified P18) has been divided in $2 \mathrm{~mL}$ Eppendorf's monodoses and used for microbiological and diffusion experiments.

Chemicals, reagents and references. Chemicals (sodium acetate, sodium carbonate and aluminium chloride), reagents (Folin-Ciocâlteu, Natural Product and Polyethylene Glycol 4000 - NP/PEG, and Vanillin-sulphuric acid - VS), solvents (ethanol, formic acid, glacial acetic acid, ethyl acetate, propylene glycol) and the reference products used in HPTLC studies (e.g., rutin (min. 95\%), chlorogenic acid (> 95\%), caffeic acid $(99 \%)$ and gallic acid (99\%)) were purchased from Merck (Fluka-Sigma-Aldrich) Co Bucharest, Romania. Qualitative analytic determination: Studies were done by (HP)TLC method according to Wagner et al. [25] and Reich et al. [31] using two solvent systems: system A (ethyl acetate:glacial acetic acid:formic acid: water, 100:12:12:26) and system B (chloroform:glacial acetic acid:methanol:water, 64:32:12:8) [21]; Silica gel 60F254 (10 x 10) HPTLC plates (Merck, Darmstadt, Germany); reference compounds mixtures prepared as $10^{-3} \mathrm{M}$ solutions in $70 \%$ ethanol; E18 and H18 test vegetal extracts loaded as $8 \mathrm{~mm}$ band length; Hamilton syringe and Linomat 5 instrument (CAMAG, Muttentz, Switzerland). The loaded plates were kept in TLC twin developing chamber at about $20^{\circ} \mathrm{C}$ with the respective mobile phase (system $\mathrm{A}$ and system $\mathrm{B}$ ) up to $90 \mathrm{~mm}$. The dried plates were immersed into detection reagents (Natural Product/NP and Polyethylene Glycol 4000/PEG for polyphenols assessment and Vanillin-sulphuric acid/VS for terpenoids compounds assessment), then they were exposed at $366 \mathrm{~nm}$ and, respectively, at white light; polyphenolic compounds 
appear as fluorescent, coloured zones (e.g. yellow, orange, green, blue-green, blue, etc.) on black, nonfluorescent plate, while terpenoidic compounds, depending on their chemical structure, appear as brown, red-brown, yellow-brown or dark green zones on the non-fluorescent white-yellow plate. The spots' assignment was done compared to the reference compounds used, and also the literature data.

Estimation of total phenolic content: The total phenolic content has been appraised by Folin-Ciocâlteu reagent, the standard method from Romanian Pharmacopoeia [33]. The results were expressed as gallic acid equivalents on dry material plant (GAE; mg/g dry weight material plant; d.w.).

Estimation of total flavonic content: The quantitative determination of flavonoids was done using the spectrophotometric aluminium chloride method ([33]), and the results were expressed in rutin equivalents (RE; mg/g dry weight material plant; d.w.).

Estimation of in vitro antioxidant activity: Studies have been done by in vitro chemiluminescence (CL) method [17] and Turner BioSystems 20/20 Luminometer equipment (SUA), as previously described [22]. Briefly, the test vegetal sample E18 has been prepared as eight dilution series in the interval 0 - $30 \mu \mathrm{g} \mathrm{GAE}$ per $1 \mathrm{~mL}$ sample (punctually $0.58,0.78,1.18,2.36$, 5.90, 11.80, 19.66, 29.5 $\mu \mathrm{g}$ GAE per $1 \mathrm{~mL}$ test sample). The results were compared with Rutin reference compound prepared as nine dilution series, in the same concentration interval, namely, 3.39, 3.82, 4.36, 5.09, 6.11, 7.64, 10.18, 15.27, $30.55 \mu \mathrm{g}$ RE per $1 \mathrm{~mL}$ sample.

Microbiological tests: Tests were done by using diffusion method in plates [33] and $20 \%$ propylene glycol standardized extract (P18). There were used three standard microbial strains: Gram-negative Escherichia coli ATCC 8739, Gram-positive Staphylococcus aureus ATCC 6538 and Candida albicans ATCC 10231 fungus (the test organisms were purchased from Mecconti s.à.r.l. Merck, Romania). The antimicrobial potency was calculated on the basis of the growth inhibition diameter, as previously described [21].

Diffusion experiments: Studies have been done on the $20 \%$ propylene glycol standardized extract (P18) with an exact content of $5 \mathrm{mg} \mathrm{GAE} / \mathrm{mL}$ sample, using an adapted Franz cell device. Studies were designed to evaluate diffusion effectiveness of the active compounds (polyphenols and terpenoids) supported on water and, respectively, on sugar, in physiological saline medium. Accordingly, two experiments have been proposed: experiment a in which $0.5 \mathrm{~g}$ of $\mathrm{P} 18$ has been homogenized with $5 \mathrm{~g}$ water then displayed on a hydrophilic cotton pad, and experiment $\mathrm{b}$ in which $0.5 \mathrm{~g}$ of P18 has been homogenized with $0.5 \mathrm{~g}$ sugar then displayed on a hydrophilic cotton pad. The two supported samples (a and b) were (separately) applied on the donor chamber glass cell (3.3 mm diameter) and covered with the diffusion cellulose acetate membrane. The donor chamber was introduced into the receptor chamber filled with $100 \mathrm{~mL}$ sterile physiological saline medium at $\mathrm{pH} 7.0$ and maintained on a magnetic stir bar at $37 \pm 1{ }^{\circ} \mathrm{C}$ and $100 \mathrm{rpm}$ stirring. Samples of $5.0 \mathrm{~mL}$ saline medium at every $5,10,15,25,35$, $45,55,65,85,105$ and 125 minutes were removed, while adding the same volume of the fresh medium. In each time point, the released compounds in saline physiological medium were determined by measuring the maximum absorption wavelength at $287 \mathrm{~nm}$ then compared to a standard calibration curve made of nine concentrations of standardized sample P18 $\left(\mathrm{R}^{2}=0.9981\right.$, $\mathrm{n}=3$ ).

Statistical analysis: All tests have been done as three $(n=3)$ consecutive measurements and the results were expressed as means \pm standard deviation $(\mathrm{M} \pm$ $\mathrm{SD})$. The active compounds kinetics and the diffusion profile of the active compounds from the standardized $20 \%$ propylene glycol extract P18, experiment a and experiment $b$ respectively, were computationally modelled by the statistically comparison of ten mathematical models (Table I). The mathematical models selected for the study were as follows: three empirical models (zero order, first order and Higuchi), four semiempirical models (Korsemeyer-Peppas, Peppas-Sahlin, HixsonCrowell and Baker-Lonsdale), and three statistical models (logistic, Gompertz and Weibull) [5].

Table I

The mathematical models selected for the study

\begin{tabular}{|c|c|c|c|}
\hline Model & Equation & Parameters & Ref. \\
\hline \multicolumn{4}{|c|}{ Empirical Models } \\
\hline Zero Order & $Q_{t}=Q_{0}+K_{0} t$ & $\begin{array}{l}\mathrm{Q}_{\mathrm{t}} \text { the quantity delivered during } \mathrm{t}, \mathrm{Q}_{0} \text { : the initial quantity from } \\
\text { solution, } \mathrm{K}_{0} \text { zero order diffusion constant }\end{array}$ & 27 \\
\hline First order & $Q_{t}=Q_{0}\left(1-\exp \left(-K_{1} t\right)\right)$ & $\begin{array}{l}\text { Qt: the quantity delivered during } \mathrm{t}, \mathrm{Q}_{0} \text { : the initial quantity from } \\
\text { solution, } \mathrm{K}_{1} \text { first order diffusion constant }\end{array}$ & 27 \\
\hline Higuchi & $Q_{t}=K_{H} \sqrt{t}+C_{H}$ & $\mathrm{Q}_{\mathrm{t}}$ the quantity delivered during $\mathrm{t}, \mathrm{K}_{\mathrm{H}}, \mathrm{C}_{\mathrm{H}}$ Higuchi constants & 8 \\
\hline \multicolumn{4}{|c|}{ Semiempirical Models } \\
\hline Korsmeyer-Pepas & $Q_{t}=C_{K P}+K_{K P} t^{n}$ & $\mathrm{Q}_{\mathrm{t}}$ the quantity delivered during $\mathrm{t}, \mathrm{K}_{\mathrm{KP}}, \mathrm{C}_{\mathrm{KP}}$ Korsmeyer-Pepas constants & 20 \\
\hline Peppas-Sahlin & $Q_{t}=K_{1} t^{n}+K_{2} t^{2 n}$ & $\mathrm{Q}_{\mathrm{t}:}$ the quantity delivered during $\mathrm{t}, \mathrm{K}_{1}, \mathrm{~K}_{2}, \mathrm{n}$ - Korsmeyer-Pepas constants & 4 \\
\hline Hixson-Crowell & $Q_{t}=Q_{0}\left[1-\left(1-K_{H K} t\right)^{3}\right]$ & $\begin{array}{l}\mathrm{Q}_{\mathrm{t}: \text { the }} \text { quantity delivered during } \mathrm{t}, \mathrm{Q}_{0:} \text { initial quantity, KHK Hixson- } \\
\text { Crowell constant }\end{array}$ & 9 \\
\hline Baker-Lonsdale & $\frac{3}{2}\left[1-\left(1-\left(\frac{Q_{t}}{Q_{\infty}}\right)\right)^{2 / 3}\right]-\frac{Q_{t}}{Q_{\infty}}=K_{m} t$ & $\begin{array}{l}\text { Qt: the quantity delivered during t, Q } \infty \text { the quantity delivered at } \\
\text { infinite time, } K m \text { : diffusion constant corresponding to the slope }\end{array}$ & 1 \\
\hline
\end{tabular}


FARMACIA, 2019, Vol. 67, 6

\begin{tabular}{|c|c|c|c|}
\hline Model & Equation & Parameters & Ref. \\
\hline \multicolumn{4}{|c|}{ Statistical Models } \\
\hline Logistic & $Q_{t}=\frac{A_{L G}}{1+\exp \left[-K_{L G}\left(t-\gamma_{L G}\right)\right]}$ & $\begin{array}{l}\text { Qt: the quantity delivered during } t, A_{L G}, K_{L G}, \gamma_{L G} \text { specific parameters } \\
\text { to the logistic model }\end{array}$ & 30 \\
\hline Gompertz & $\begin{array}{l}Q_{t}=A_{G P} \exp \left[-\exp \left(-K_{G P}\left(t-\gamma_{G P}\right)\right)\right] \\
Q_{t}=Q_{0}+A_{G P} \exp \left[-\exp \left(-K_{G P}\left(t-\gamma_{G P}\right)\right)\right]\end{array}$ & $\begin{array}{l}\text { Qt: the quantity delivered during t, } \mathrm{Q}_{0:} \text { the initial quantity, AGP, } \mathrm{K}_{\mathrm{GP}} \\
\gamma_{\mathrm{GP}} \text { specific parameters to the Gompertz model }\end{array}$ & $\begin{array}{c}24, \\
12\end{array}$ \\
\hline Weibull & $Q_{t}=1-\exp \left[\frac{-\left(t-T_{i}\right)^{b}}{a}\right]$ & $\begin{array}{c}\text { Qt: the quantity delivered during } t \text {, time scale, } b \text { shape parameter, } T_{i} \\
\text { time interval previous to the diffusion process }\end{array}$ & $\begin{array}{l}4, \\
23\end{array}$ \\
\hline
\end{tabular}

The model estimation was carried out by non-linear parameter optimization by the use of the MarquardtLevenberg method [16], the initial values being obtained by linearizing the models. The nonlinear optimization method has been preferred since, although most models have linearized expressions, the truncation of the results and the transformation errors can damage the final result. The computer program was developed in the MATLAB R2010 environment, by the use of the 1sq curve fit function. The model discrimination was carried out by firstly determining the minimum of the statistical coefficients and, secondly, by the general visual evaluation of the experimental data fitting. As statistical coefficients we used squared and the adjusted correlation coefficient $\left(\mathrm{R}^{2}, \mathrm{R}^{2}{ }_{\text {adj }}\right)[5,27]$, mean square error of the regression (MSE) [8], mean

$$
\text { absolute error (MAE) } M A E=\frac{\left.\sum_{i=1}^{n} \mid y_{i}-y_{i}\right]^{2}}{n}
$$

[20],

root mean square error (RMSE) [4], and regression through origin (RTO) [9]. Regarding the $\mathrm{R}^{2}$ correlation, it always increases or remains constant as new parameters are added to the model. As a result, in the scientific literature is used the adjusted
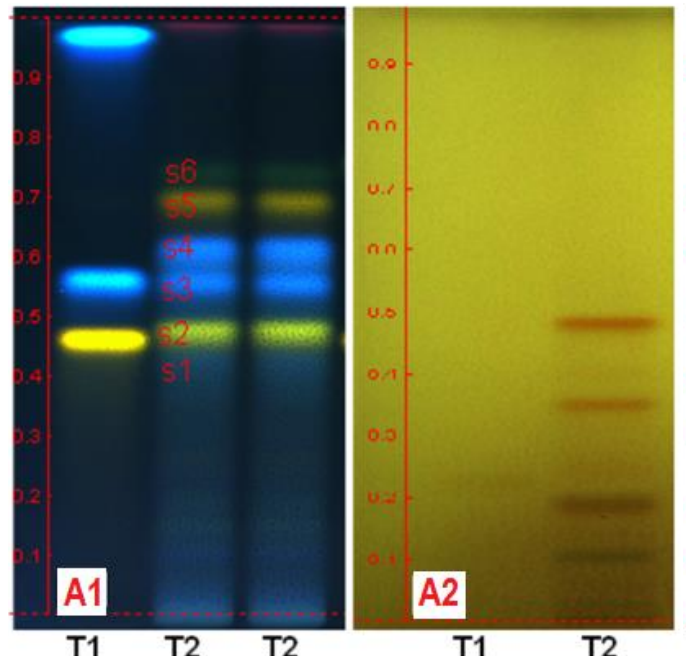

T2

$\mathrm{R}^{2}$ which might decrease providing an indication of the contribution of the new parameters in the model; the model with a maximum adjusted correlation coefficient value and a minimum value of the other statistical coefficients is the optimum model for the performed experiment [4].

\section{Results and Discussion}

\section{Qualitative analytic determination}

HPTLC analyses (Figure 1) have been done on $70 \%$ ethanolic extract (E18) and corresponding hydrolysed sample (H18); thus, system A setting study [21] and NP/PEG treatment on E18 (chromatogram A1, T2 tracks) indicated the occurrence of six major polyphenols compounds of which rutin/quercetin-3-Orutinoside (s2), hyperoside/quercetin-3-O-galactoside (s5), cosmosiin/apigenin-7-O-glucoside (s6), chlorogenic (s3) and neochlorogenic (s4) acid; system A setting study on E18 and VS treatment (chromatogram A2, T2 track) also revealed the presence of several terpenoid compounds (likely glycosides form), the four green and red-brown zones at $\mathrm{R}_{\mathrm{f}} \sim 0.3-0.6$ respectively.
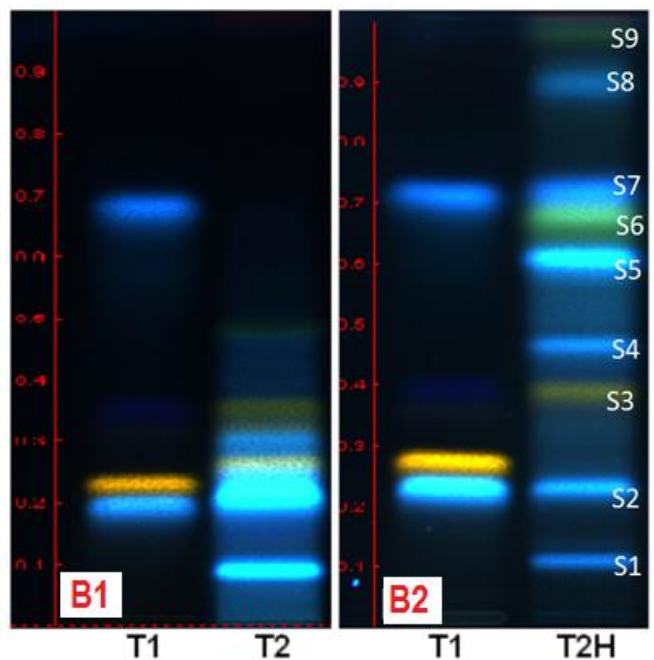

Figure 1.

(HP)TLC aspects of 70\% ethanolic extract (E18) and corresponding hydrolysed sample (H18) from the aerial part of Acinos alpinus in comparison with several references compounds (ref.) - system A setting study and system B setting study respectively

Chromatogram A1 - Track 1, rutin, chlorogenic acid and caffeic acid (ref.); Tracks 2, ethanolic extracts (E18) - NP/PEG treatment. Chromatogram A2 - Track 2, ethanolic extract (E18) - VS treatment. Chromatogram B1 - Track 1, chlorogenic acid, rutin, gallic acid and caffeic acid (ref.); Track 2, ethanolic extract E18 - NP/PEG treatment. Chromatogram B2 -Track

1, rutin, chlorogenic acid, gallic acid and caffeic acid (ref.); Track $2 \mathrm{H}$, the hydrolysed extract H18 - NP/PEG treatment. 
Designed to achieve a better understanding of polyphenols profile in vegetal extracts by disclosing the aglycone core from their glycosides and other complex molecules, system B setting study [21] and NP/PEG treatment on the ethanolic extracts E18 (chromatogram B1, T2 track) face to corresponding hydrolysed sample H18 (chromatogram B2, T2H track) confirmed chlorogenic acid (s2) presence and caffeoyl quinic acid (s7) structure of phenyl carboxylic acids in Acinos alpinus plant species; hyperoside (s3, $R \mathrm{f} \sim 0.39)$ and corresponding quercetin aglycone $\left(\mathrm{s} 6, \mathrm{R}_{\mathrm{f}} \sim 0.68\right)$ as well as apigenin $(R \mathrm{f} \sim 0.96)$ and kaempferol $(R \mathrm{f} \sim$ 0.89 ) aglycones attendance were also proved, thus confirming quercetin, apigenin and kaempferol glycosides presence in ethanolic extracts from the aerial part of Acinos alpinus.

Concerning the chemical quantitative aspects, the aerial part of Acinos alpinus from Romanian Carpathian Mountains has been appraised with $24.6 \mathrm{mg}$ total flavones content expressed as rutin equivalents (RE; $\mathrm{mg} / \mathrm{g}$; d.w.) and $16.5 \mathrm{mg}$ total phenols content expressed as gallic acid equivalents (GAE; mg/g; d.w.).

In vitro antioxidant activity results

Literature data confirm the antioxidant (DPPH, FRAP methods) and anti-inflammatory properties (carrageenan induced paw oedema in rats assay) of the volatile oils fraction [10] and leaves extracts [3] from specific Acinos species. The present study was conducted on $70 \%$ ethanolic extract (E18) from the aerial part of Acinos alpinus indicated a moderate antioxidant effect (Figure 2) estimated at $\mathrm{IC}_{50}=2.04 \mu \mathrm{g}$ GAE/ $\mathrm{mL}$ extract, so that similar to that of rutin reference compound $\left(\mathrm{IC}_{50}=2.54 \mu \mathrm{g} \mathrm{GAE} / \mathrm{mL}\right)$; for comparison, under identical study conditions, other vegetal extracts studied by the authors indicated $\mathrm{IC}_{50}$ values ranging from 0.25 to $4.20 \mu \mathrm{g}$ GAE $/ \mathrm{mL}$ (Table II).

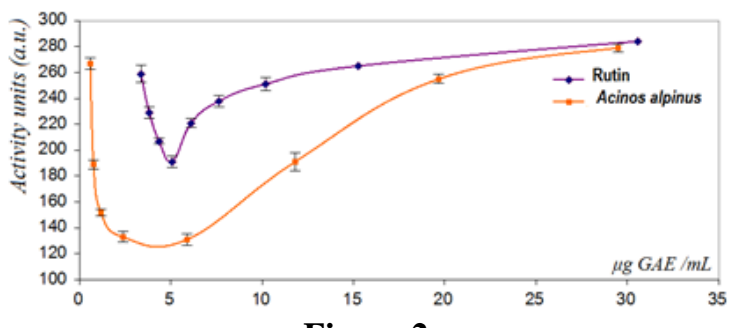

Figure 2.

Chemiluminescence studies ( $\mathrm{IC}_{50}$ assay) on the $70 \%$ ethanolic extract (E18) from Acinos alpinus plant species in comparison with the reference compound rutin (ref.)

Table II

Antioxidant activity $\left(\mathrm{IC}_{50}\right)$ of several vegetal extracts from Romanian flora comparatively to gallic acid and rutin reference compounds (ref.)

\begin{tabular}{|l|c|}
\hline \multicolumn{1}{|c|}{ Plant material description / type of extract / solvent } & $\mathrm{IC}_{50}(\mu \mathrm{g} \mathrm{GAE} / \mathrm{mL})$ \\
\hline Acinos alpinus L. herba et flores / ethanolic extract & 2.36 \\
\hline Heliantheum nummularium L. herba et flores / ethanolic extract & 1.27 \\
\hline Phyteuma confusum L. herba et flores / ethanolic extract & 0.34 \\
\hline Polygonum bistorta L. herba et flores / ethanolic extract & 0.57 \\
\hline Geranium robertianum L. herba et flores / ethanolic extract & 0.58 \\
\hline Geranium phaeum L. herba et flores / ethanolic extract & 2.57 \\
\hline Gentiana lutea L. flores / ethanolic extract & 0.25 \\
\hline Petasites hybridus L. flores / ethanolic extract & 1.10 \\
\hline Centaurea cyanus L. herba et flores / ethanolic extract & 3.12 \\
\hline Centaurea cyanus L. herba et flores / aqueous extract & 4.20 \\
\hline Gallic acid (ref.) / ethanol 70 \% & 0.85 \\
\hline Rutin (ref.) / ethanol 70\% & 2.54 \\
\hline
\end{tabular}

Antimicrobial activity

Microbiological study upon $20 \%$ propylene glycol standardized extract (P18) tested on the three microbial strains indicated very weak antimicrobial activity on Escherichia coli ATCC 8739 and Staphylococcus aureus ATCC 25923, and no activity on Candida albicans ATCC 10231 strain (Table III); 20\% propylene glycol solution (the solvent in which the test sample P18 has been prepared) showed no antimicrobial activity.

Table III

Antimicrobial activities of Acinos alpinus L. propylene glycol extract P18

\begin{tabular}{|c|c|c|}
\hline Plant material description / type of extract & Microbial strains studied & Inhibition zone diameter (mm) \\
\hline Acinos alpinus L. - herba et flores & Staphylococcus aureus ATCC 6538 & $8.5 \pm 0.04$ \\
\cline { 2 - 3 } 20\% propylene glycol extract & Escherichia coli ATCC 8739 & $8.5 \pm 0.13$ \\
\cline { 2 - 3 } & Candida albicans ATCC 10231 & $<8$ \\
\hline
\end{tabular}

Values are mean inhibition zone $(\mathrm{mm}) \pm$ S.D. of three replicates; Were diam. $<8 \mathrm{~mm}$ means no activity; diam. $8-10 \mathrm{~mm}$ means very weak activity; diam. $10-15 \mathrm{~mm}$ means weak activity; diam. $16-20 \mathrm{~mm}$ means moderate activity and diam. $>20 \mathrm{~mm}$ means certain activity. 
FARMACIA, 2019, Vol. 67, 6

Diffusion experiments

The diffusion profile of the active compounds found in $20 \%$ propylene glycol standardized extract (P18) from the aerial part of Acinos alpinus has been carried out by using the models presented in the statistical analysis section. The models were compared by the use of the statistical coefficients shown above [5, $27,8,20,4]$, the optimum model being selected by the maximum value of the adjusted coefficient of determination and the minimum values of the other coefficients. The complete values of the statistical coefficients are presented in Table IV.

Table IV

Statistical coefficients of the studied experiments (experiment a and experiment b)

\begin{tabular}{|c|c|c|c|c|c|}
\hline Model & $R_{\text {adj }}^{2}$ & MSE & RMSE & MAE & RTO \\
\hline \multicolumn{6}{|c|}{ Order 0} \\
\hline Experiment a & 0.9468 & 2.7205 & 2.3201 & 1.8411 & 0.9886 \\
\hline Experiment $b$ & 0.4585 & 14.6657 & 13.2656 & 11.4907 & 0.9446 \\
\hline \multicolumn{6}{|c|}{ Order 1} \\
\hline Experiment a & 0.9906 & 1.1460 & 1.0366 & 0.8121 & 0.9977 \\
\hline Experiment b & 0.9642 & 3.7729 & 3.4127 & 2.9831 & 0.9963 \\
\hline \multicolumn{6}{|c|}{ Baker - Lonsdale } \\
\hline Experiment a & 0.8909 & 3.8981 & 3.7167 & 3.4158 & 0.9651 \\
\hline Experiment b & 0.7509 & 9.9467 & 9.4838 & 8.5348 & 0.9968 \\
\hline \multicolumn{6}{|c|}{ Higuchi } \\
\hline Experiment a & 0.9821 & 1.5794 & 1.4286 & 1.2305 & 0.9957 \\
\hline Experiment b & 0.5510 & 13.3548 & 12.0799 & 10.5168 & 0.9540 \\
\hline \multicolumn{6}{|c|}{ Korsmayer - Peppas } \\
\hline Experiment a & 0.9814 & 1.6102 & 1.3732 & 1.1261 & 0.9960 \\
\hline Experiment $b$ & 0.7270 & 10.4135 & 9.4194 & 8.3944 & 0.9721 \\
\hline \multicolumn{6}{|c|}{ Peppas - Sahlin } \\
\hline Experiment a & 0.9822 & 1.5764 & 1.3443 & 1.0888 & 0.9962 \\
\hline Experiment $b$ & 0.9323 & 5.1866 & 4.4232 & 3.9499 & 0.9938 \\
\hline \multicolumn{6}{|c|}{ Hixon - Crowell } \\
\hline Experiment a & 0.9572 & 2.4426 & 2.3289 & 1.8937 & 0.9979 \\
\hline Experiment $b$ & 0.2330 & 17.4549 & 16.6426 & 14.4560 & 1.1131 \\
\hline \multicolumn{6}{|c|}{ Gompertz } \\
\hline Experiment a & 0.9961 & 0.7334 & 0.6254 & 0.5521 & 0.9992 \\
\hline Experiment $b$ & 0.9961 & 1.2520 & 1.0677 & 0.9011 & 0.9996 \\
\hline \multicolumn{6}{|c|}{ Logistic } \\
\hline Experiment a & 0.9945 & 0.8724 & 0.7440 & 0.6137 & 0.9988 \\
\hline Experiment $b$ & 0.9937 & 1.5766 & 1.3445 & 1.1212 & 0.9944 \\
\hline \multicolumn{6}{|c|}{ Weibull } \\
\hline Experiment a & 0.9970 & 0.6518 & 0.5199 & 0.4859 & 0.9994 \\
\hline Experiment $b$ & 0.9967 & 1.1421 & 0.9111 & 0.8027 & 0.9938 \\
\hline
\end{tabular}

$\mathrm{R}^{2}$ adj - adjusted correlation coefficient, MSE - mean square error of the regression, RMSE - root mean square error, MAE - mean absolute error, RTO - regression through origin

Therefore, examining Table IV, it is worth noting for both $\mathrm{R}_{\text {adj }}^{2}$, MSE and other statistical coefficients that for the maximum adjusted correlation coefficient can be written the following order of inequalities can be drown: Order 1 < Logistic < Gompertz < Weibull. For the other statistical coefficients the same set of entities in decreasing order is noticed. Figure 3 and Figure 4 show the experimental and theoretical (First order, Logistic, Gompertz and Weibull model) profiles of the sample P18 in the two experiments; the diffusion profile of the active compounds in Acinos alpinus $20 \%$ propylene glycol extract supported on water (experiment a) and sugar (experiment b), in physiological saline medium at $\mathrm{pH} 7.0$ respectively.

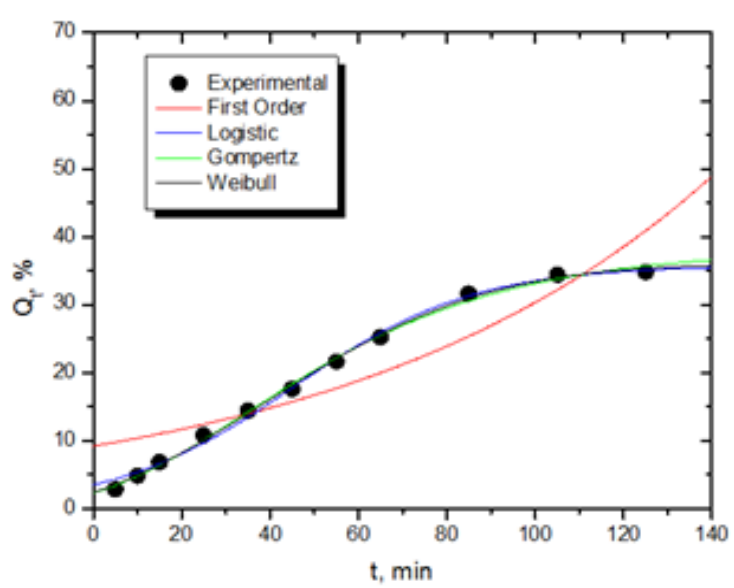

Figure 3.

Diffusion profile of the P18 sample supported on a water basis (experiment a) 


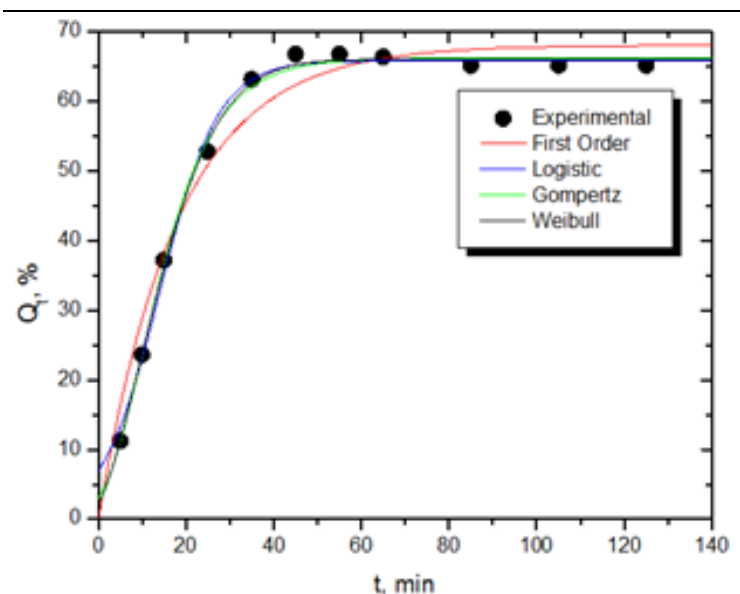

Figure 4.

Diffusion profile of the P18 sample supported on a sugar basis (experiment b)

Accordingly, it is noted that the logistic, Gompertz and Weibull models, have a similar behaviour, but from the graphical evaluation it results that both the logistic and Weibull model are over fitting the experimental data, especially for the debut and saturation values of the experimental data. For this reason, the Gompertz model was chosen as the optimal diffusion model. This model is frequently applied to the growth in number or density of microbes $[6,15]$, growth of tumours $[13,14,18]$, and the survival of cancer patients [28].
The trend plot of a Gompertz model shows a phase in which the specific growth rate starts from a zero value and increases to a maximum value $\left(\mu_{\mathrm{m}}\right)$, leading to a lag time $(\lambda)$ followed by a final state characterized by a plateau (A) [9]. Zwietering et al. [32] proposed a re-parameterization of the Gompertz function [9] which is often called a "modified Gompertz" [7], given as:

$$
Q_{t}=A \exp \left[-\exp \left(\frac{\mu_{m} e}{A}(\lambda-t)+1\right)\right]
$$

where the significance of $A, \mu_{m}$ and $\lambda$ were previously explained. Starting from the Gompertz function profile:

$$
Q_{t}=A_{G P} \exp \left[-\exp \left(-K_{G P}\left(t-\gamma_{G P}\right)\right)\right]
$$

the parameters of modified one may be computed by the equations:

$$
\begin{gathered}
A=A_{G P} \quad[30], \\
\lambda=\frac{K_{G P} \gamma_{G P}-1}{K_{G P}} \\
\mu_{m}=\frac{A_{G P} K_{G P}}{e}
\end{gathered}
$$

By the use of the above equations, the parameters of the Gompertz model for the two experiments have been computed (Table V).

Table V

Gompertz parameter of the studied experiments

\begin{tabular}{ccccccc} 
Study & $\mathrm{A}_{\mathrm{GP}}$ & $\mathrm{K}_{\mathrm{GP}}$ & $\gamma_{\mathrm{GP}}$ & $\mathrm{A}$ & $\lambda$ & $\mu_{\mathrm{m}}$ \\
\hline Experiment a & 38.1876 & 0.0297 & 34.5811 & 38.1876 & 0.9508 & 0.4177 \\
Experiment b & 66.2465 & 0.1107 & 10.2453 & 66.2465 & 1.212 & 2.6979
\end{tabular}

$\mathrm{A}_{\mathrm{GP}}, \mathrm{K}_{\mathrm{GP}}, \gamma_{\mathrm{GP}}$ - specific parameters of the Gompertz model; $\mu_{\mathrm{m}}$ - slope of the growth rate; $\lambda$ - lag time; A - plateau

Table V clearly reveals that the experiment b (P18 on sugar-support) is characterized by an upper plateau (A) and slope $\mu_{\mathrm{m}}$ values, suggesting that the diffusion process of the active compounds from Acinos alpinus take places more intense and faster if the plant extracts are placed on a sugar basis. As numeric values, while water-supported sample indicated a maximum diffusion percent of $35 \%$ at 125 minutes, the sugar-supported sample indicated a maximum diffusion percent of $67 \%$ at 45 minutes.

Also, the lag time $(\lambda)$ values were very appropriate in the two experiments suggesting a similitude as concerning the necessary time to initiate Acinos alpinus active compounds diffusion process in a saline physiological medium

\section{Conclusions}

The literature data on Acinos sp. is relatively scarce and mainly refers to antimicrobial and anti-inflammatory properties of the volatile oils fraction; Romanian folk medicine does not contain any information about this plant species and its potential use benefits on human health. The present study on the aerial part of Acinos alpinus collected from Romanian Carpathian Mountains has revealed a chemical content of $24.6 \mathrm{mg}$ total flavones content expressed as rutin equivalents (RE; mg/g dry weight material plant; d.w.) and 16.5 mg total phenols content expressed as gallic acid equivalents (GAE; mg/g dry weight material plant; d.w.). Concerning qualitative aspects, HPTLC analyses indicated the occurrence of quercetin, apigenin, kaempferol and caffeic acid derivatives, aside from several augmented terpenoid compounds, together responsible for the flavour, and aperitif and digestive properties of the species. The $70 \%$ ethanolic extract and $20 \%$ propylene glycol standardized extract $(5 \mathrm{mg}$ GAE $/ \mathrm{mL}$ ) from the aerial part of Acinos alpinus have shown moderate antioxidant activity $\left(\mathrm{IC}_{50}=2.04 \mu \mathrm{g} /\right.$ $\mathrm{mL}$ ) and poor or non-existent antimicrobial activity on the tested microbial strains (Escherichia coli ATCC 8739, Staphylococcus aureus ATCC 6538 and Candida albicans ATCC 10231). Franz cell studies on $20 \%$ propylene glycol standardized extract indicated a more 
intense and faster diffusion process for a test sample combined with sugar. The results suggest that sugarbased formulations (for example syrups or liqueurs) from Acinos alpinus may have better aperitifs or digestive properties than aqueous extracts (e.g. teas, infusions or decoctions). Sugar-based formulations could also form the basis of functional foods and other ingredients for fine pastry, beneficial for the digestive process in humans.

\section{Acknowledgement}

This work was supported by the ANCSI program POC-A1-A1.2.3-G-2015, Project title <New technologies and natural derived products for human health use >, Contract no.60/05.09.2016, ID P_40_406, SMIS 105542.

\section{References}

1. Baker RW, Lonsdale HS, Controlled released: mechanisms and rates. Controlled Release of Biologically Active Agents, New York, Plenum Press, 1974; 15-71.

2. Carović-Stanko K, Petek M, Grdiša M, Pintar J, BedeKović D, Herak-Custić M, Satovic Z, Medicinal Plants of the Family Lamiaceae as Functional Foods - a Review. Czech J Food Sci., 2016; 34(5): 377-390.

3. Conforti F, Marrelli M, Statti G, Menichini F, Uzunov D, Solimene U, Menichini F, Comparative chemical composition and antioxidant activity of Calamintha nepeta (L.) Savi subsp. glandulosa (Req.) Nyman and Calamintha grandiflora (L.) Moench (Labiatae). Nat Prod Res., 2012; 26: 91-97.

4. Costa P, Sousa LJM, Modelling and comparison of dissolution profiles. Eur J Pharm Sci., 2001; 13: 123-133.

5. Ghosal K, Chandra A, Rajabalaya R, Chakraborty S, Nanda A, Mathematical modelling of drug release profiles for modified hydrophobic HPMC based gels. Pharmazie, 2012; 67: 147-155.

6. Gibson AM, Bratchell N, Roberts TA, The effect of sodium chloride and temperature on the rate and extent of growth of Clostridium bolulinum type A in pasteurized pork slurry. J Appl Bacteriol., 1987; 62(6): 479-490.

7. Halmi MIE, Shukor MS, Johari WLW, Shukor MY, Evaluation of several mathematical models for fitting the growth of the algae Dunaliella tertiolecta. AJPB, 2014; 2(1): 1-6.

8. Higuchi T, Rate of release of medicaments from ointment bases containing drugs in suspension. $J$ Pharm Sci., 1961; 50: 874-875.

9. Hixon AW, Crowell JH, Dependence of reaction velocity upon surface and agitation: I-Theoretical consideration. Ind Eng Chem., 1931; 23: 923-931.

10. Jennan S, Fouad R, Farah A, Bousta D, Mahjoubi F, Antioxidant, anti-inflammatory and antinociceptive activities of essential oils of three Satureja species ( $S$. briquetti, S. atlantica and S. alpina) growing wild in the Middle Atlas Mountains of Morocco. Der Pharma Chem., 2018; 10(6): 75-80.

11. Jovanovic T, Kitic D, Palic R, Stojanovic G, Ristic $\mathrm{M}$, Chemical composition and antimicrobial activity of the essential oil of Acinos arvensis (Lam.) Dandy from Serbia. Flavour Fragr J., 2005; 20: 288-290.

12. Kleinubing SA, Seraphim DC, Adeodato VMG, Canevesi RLS, da Silva DA, Cezar LE, Innocentini LM, Gastro-resistant controlled release of OTC encapsulated in Alginate/Chitosan matrix coated with Acryl-EZE ${ }^{\circledR} \mathrm{MP}$ in Fluidized Bed. J Appl Polym Sci., 2014; 131(12): 1-9.

13. Laird AK, Dynamics of tumor growth. Br J Cancer, 1964; 18: 490-502.

14. Laird AK, The dynamics of growth. Res Dev., 1969; 20(8): 28-31.

15. Lopez S, Prieto M, Dijkstra J, Dhanoa MS, France $\mathrm{J}$, Statistical evaluation of mathematical models for microbial growth. Int J Food Microbiol., 2004; 96(3): 289-300

16. Marquardt DW, An Algorithm for Least-Squares Estimation of Nonlinear Parameters. J Soc Indust and Appl Math., 1963; 11(2): 431-441.

17. Meghea A, Iftimie N, Giurginca M, Papadopoulos K, Quantification of oxidative stress in biosystems. I. Chemiluminescence test and antioxidant activity of molecules of biological interest. Rev Chem., 2003; 54(11): 885-887.

18. Norton L, A Gompertzian model of human breast cancer growth. Cancer Res., 1988; 48: 7067-7141.

19. Pardo de Santayana M, Blanco E, Morales R, Plants known as té in Spain: An ethno-pharmaco-botanical review. J Ethnopharmacol., 2005; 98: 1-19.

20. Peppas NA, Analysis of Fickian and non-Fickian drug release from polymers. Pharm Acta Helv., 1985; 60: 110-111.

21. Pirvu L, Hlevca C, Nicu I, Bubueanu C, Comparative studies on analytical, antioxidant, and antimicrobial activities of a series of vegetal extracts prepared from eight plant species growing in Romania. $J P C-J$. Planar Chromat., 2014; 27(5): 346-356.

22. Pirvu L, Sha' at F, Miclea LC, Savopol T, Neagu G, Udeanu DI, Moisescu MG, Polygonum bistorta L. herba et flores. Polyphenols profile, antioxidant properties and cytotoxic effect on murine fibroblast cell line (NIH 3T3). Farmacia, 2017; 65(4): 571-576.

23. Polli EJE, Rekhi ES, Augsburger LL, Shah VP, Methods to compare dissolution profiles and a rationale for wide dissolution specifications for metoprolol tartrate tablets. J Pharm Sci., 1997; 86: 690-700.

24. Ramteke KH, Dighe PA, Kharat A, Patil SV, Mathematical models of drug dissolution: A review. Sch Acad J Pharm., 2014; 3(5): 388-396.

25. Reich E, Schibli A, HPTLC for the analysis of medicinal plants. Thieme, N.Y.-Stuttgart, 2008; 67-116.

26. Stojanovi G, Golubovi T, Kiti D, Pali R, Acinos species: Chemical composition, antimicrobial and antioxidative activity. J Med Plant Res., 2009; 3(13): 1240-1247.

27. Shah MV, De Gennaro MD, Suryakasuma H, An evaluation of albumin microcapsules prepared using a multiple emulsion technique. J Microencaps., 1987; 4: $223-238$.

28. Trachtenberg HL, The wider application of the Gompertz law of mortality. J R Stat Soc., 1924; 87(2): 278-290.

29. Ulukanli Z, Ulukanli S, Ozbay H, Ilcim A, Tuzcu M, Antimicrobial Activities of Some Plants from the 
FARMACIA, 2019, Vol. 67, 6

Eastern Anatolia Region of Turkey. Pharm Biol., 2005; 43(4): 334-333.

30. Verhulst PF, Notice sur la loi que la population suit dans son accroissement. Correspondance Mathematique et Physique, 1938; 10: 113-121.

31. Wagner H, Bladt S, Plant Drug Analysis. $2^{\text {nd }}$ Ed., Berlin Heidelberg, Springer, 1996; 195-245.
32. Zwietering MH, Jongenburger I, Rombouts FM, Van'T Rie TK, Modeling of the bacterial growth Curve. Appl Env Microbiol., 1990; 56(6): 1975-1981.

33. ***Farmacopeea Română, ediţia a X-a. Bucureşti, Ed. Medicală, 1993; 334-335, 1063-1064, (available in Romanian). 